\title{
Garbage collectors, far from health: A study of dermatitis in Middle Java, Indonesia
}

\author{
Grefima Pramudani*1 ${ }^{1}$ Ipop Sjarifah ${ }^{2}$, Yusuf Ari Mashuri ${ }^{3}$ \\ ${ }^{1,2}$ Bagian Keselamatan dan Kesehatan Kerja, Universitas Sebelas Maret, Surakarta \\ ${ }^{3}$ Bagian Kedokteran, Universitas Sebelas Maret, Surakarta
}

DOI: 10.24252 /al-sihah.v12i2.15434

Received: 21 August 2020 / In Reviewed: 25 August 2020/ Accepted: 11 September 2020 / Available online: 17 September 2020 C The Authors 2020. This is an open access article under the CC BY-NC-SA 4.0 license

\begin{abstract}
Household garbage collectors are one of the groups who are at risk of getting dermatitis due to their work. This study aims to determine the relationship between the length of service and the use of long-sleeved work clothes and gloves with dermatitis on the household garbage collector in Surakarta. This was an observational analytic study using a cross-sectional study. The subjects of the study were household garbage collector in Jebres subdistrict, Surakarta. A total of 134 respondents was recruited as samples using simple random sampling. A questionnaire sheet was used to collect individual data and dermatitis status was determined by the doctor's diagnosis. A Chi-square test was used to investigate the relationship between the length of service and the use of longsleeved work clothes and gloves with dermatitis. Logistic regression was used to determine factors associated with dermatitis. There was a significant relationship between the length of service with dermatitis $p=0.000$ $(p<0.05)$. There was also a significant relationship between long-sleeve work clothes and gloves with dermatitis $p=0.003$ ( $p<0.05)$. The multivariable test showed that workers with a long length of service had a higher risk of having dermatitis compared to a short length of service $(O R=6,701, p=0.000)$. It was also showed that more frequent use of long-sleeved work clothes intensity reduces the risk of getting dermatitis compared to sometimes use $(O R=0.341, p=0.017)$. There is a significant association between the length of work and the use of long-sleeved work clothes and gloves with dermatitis on household garbage collectors in Surakarta.
\end{abstract}

Keyword: dermatitis; garbage collector; length of service; personal protective equipment

\begin{abstract}
ABSTRAK
Pekerja pengangkut sampah merupakan salah satu kelompok yang berisiko terkena dermatitis akibat dari kontak langsung maupun tidak langsung dengan sampah yang diangkutnya. Hal ini bisa terjadi karena sampah rumah tangga mengandung sampah bahan berbahaya dan beracun (B3) rumah tangga, jamur serta bakteri. Penelitian ini bertujuan untuk mengetahui hubungan masa kerja dan penggunaan baju kerja lengan panjang dan sarung tangan dengan dermatitis pada pekerja pengangkut sampah di Surakarta. Jenis penelitian ini merupakan penelitian observasional analitik dengan studi cross sectional. Subjek penelitian adalah para pekerja pengangkut sampah di Kecamatan Jebres, Surakarta. Total responden sebanyak 134 pekerja didapatkan dengan metode simple random sampling. Instrumen yang digunakan berupa lembar kuesioner dan diagnosis dari dokter. Uji bivariat menggunakan Chi square dan uji multivariabel menggunakan regresi logistik berganda Terdapat hubungan yang signifikan antara masa kerja dengan dermatitis $\mathrm{p}=0.000(\mathrm{p}<0.05)$. Terdapat hubungan yang signifikan antara penggunaan baju kerja lengan panjang dengan dermatitis $\mathrm{p}=0.003(\mathrm{p}<0.05)$. Pada uji multivariabel menunjukkan bahwa masa kerja lama mempunyai risiko terkena dermatitis 6,701 kali lebih besar dibandingkan dengan masa kerja baru $(O R=6,701 ; p=0.000)$. Penggunaan baju kerja lengan panjang dan sarung tangan yang sering dapat menurunkan risiko terkena dermatitis $(\mathrm{OR}=0.341 ; \mathrm{p}=0.017)$. Terdapat hubungan antara masa kerja, penggunaan baju kerja lengan panjang dan sarung tangan dengan dermatitis pada pekerja pengangkut sampah di Surakarta.
\end{abstract}

Kata kunci: alat pelindung diri; dermatitis; masa kerja; pengangkut sampah

*Alamat Korespondensi:

Jogoyudan RT 19/RW 09, Wates, Kulon Progo, 55651

Email: grefimapramudani@gmail.com 


\section{PENDAHULUAN}

Pengelolaan limbah padat yang tidak memadai dapat berdampak pada kesehatan dan secara langsung dapat memengaruhi kualitas hidup masyarakat di negara-negara berkembang (Cruvinel et al., 2019). Di Indonesia, belum ada sistem pengelolaan sampah yang tepat sebelum dibuang ke tempat pembuangan akhir. Sebagian besar tempat pembuangan sampah di Indonesia sudah melebihi kapasitas dan membutuhkan perawatan intensif (Lokahita et al., 2019). Rata-rata, Indonesia menghasilkan sampah $0,76 \mathrm{~kg} / \mathrm{hari}$, dengan jumlah penduduk 253 juta pada tahun 2014, Indonesia dapat menghasilkan sampah rumah tangga sekitar 190.000 ton/hari yang terdistribusi di 34 provinsi dan lebih dari 465 kota madya (Sudibyoa et al., 2017).

Pekerjaan mengumpulkan sampah adalah pekerjaan yang berpotensi menimbulkan beberapa penyakit (Cruvinel, 2019), di antaranya adalah penyakit dermatitis (Nam et al., 2020). Prevalensi kejadian dermatitis dapat dipengaruhi frekuensi kontak yang sering dan masa kerja yang lama (Pradananingrum et al., 2018). Penelitian yang dilakukan oleh Sarfiah et al., (2016) menunjukkan ada hubungan yang signifikan antara kejadian dermatitis kontak iritan dan lama kerja. Oleh karena itu, pemakaian alat pelindung diri (APD) sangat diperlukan dalam semua aspek pekerjaan, terutama dalam hal perlindungan penyakit. Alat pelindung diri yang wajib dikenakan oleh pekerja pengangkut sampah antara lain, pakaian khusus kerja, safety helmet, hands scoon, dan sepatu bot. Peralatan tersebut digunakan agar pekerja terhindar dari kejatuhan benda, tersengat aliran listrik, terkena benda tajam, terjangkit penyakit bawaan sampah, maupun iritasi kulit karena bersentuhan langsung dengan zat-zat berbahaya yang terkandung dalam sampah yang bercampur (Wijayanti, 2015).

Undang-undang No. 1 Tahun 1970 tentang keselamatan kerja mengemukakan bahwa tenaga kerja berhak meminta kepada pemberi kerja agar dilaksanakan semua syarat keselamatan dan kesehatan yang diwajibkan pemerintah. Selain itu, undangundang No.13 Tahun 2003 tentang Ketenagakerjaan menyebutkan bahwa pekerja berhak memperoleh keselamatan dan kesehatan kerja, maka dari itu kesehatan pekerja merupakan hal yang harus dikaji lebih lanjut.

Kecamatan Jebres merupakan salah satu kecamatan yang ada di Kota Surakarta. Kecamatan tersebut memiliki sebelas kelurahan dengan luas kawasan mencapai $12,60 \mathrm{~km} 2$. Jumlah masyarakat yang tinggal di kecamatan tersebut mencapai 145.676 jiwa (Badan Pusat Statistik Kota Surakarta, 2019). Pertumbuhan penduduk, peningkatan aktivitas manusia, pertumbuhan ekonomi, 
dan tingginya tingkat urbanisasi di kotakota dapat berpotensi membawa peningkatan jumlah sampah (Zulfinar \& Sembiring, 2015).

Pengangkutan sampah di Surakarta dilakukan oleh petugas pengangkut sampah dengan menggunakan peralatan seperti gerobak maupun truk sampah (Lesmana, 2016). Kegiatan pengangkutan sampah tersebut dapat menyebabkan berbagai dampak bagi petugas pengangkut sampah. Salah satu dampak tersebut yaitu adanya penyakit dermatitis kontak iritan yang dapat diderita oleh para petugas tersebut (Elviarni \& Dode, 2018). Pada hasil observasi diketahui bahwa pemisahan sampah yang belum berjalan saat pengangkutan sampah menyebabkan semua sampah bercampur tanpa tahu bahan sisa apa saja yang ada di dalam campuran sampah tersebut.

Tujuan penelitian ini adalah untuk mengetahui hubungan masa kerja dan penggunaan baju kerja lengan panjang dan sarung tangan dengan kejadian dermatitis pada pekerja pengangkut sampah di Surakarta, Provinsi Jawa Tengah, Indonesia.

\section{METODE PENELITIAN}

Penelitian ini merupakan penelitian observasional analitik menggunakan studi cross sectional untuk mengetahui hubungan antar variabel. Penelitian dilakukan di Kecamatan Jebres, Kota Surakarta,
Provinsi Jawa Tengah, Indonesia, yang dilaksanakan pada bulan Januari sampai bulan Agustus 2020. Subjek penelitian adalah petugas pengangkut sampah yang bekerja di wilayah Kecamatan Jebres, Surakarta dengan total populasi sebanyak 201 pekerja dan sampel sebesar 134 petugas pengangkut sampah yang terpilih menggunakan teknik simple random sampling.

Variabel bebas dalam penelitian ini adalah masa kerja dan penggunaan baju kerja lengan panjang dan sarung tangan. Sedangkan variabel terikat dalam penelitian ini adalah dermatitis. Pengambilan data dimulai dari pengumpulan data nama-nama pekerja pengangkut sampah yang ada di Kecamatan Jebres. Setelah didapatkan responden dengan simple random sampling, responden diminta mengisi kuesioner berisi data diri dan keluhan dermatitis yang dialami. Apabila mengalami gejala dermatitis, maka responden akan diperiksa oleh dokter. Penegakan diagnosis dermatitis dilakukan oleh dokter umum. Penelitian ini telah dinyatakan layak etik oleh Komisi Etik Penelitian Kesehatan RSUD Dr. Moewardi melalui surat kelayakan etik Nomor 206/1/HREC/2020. Seluruh responden menyetujui untuk ikut serta dalam penelitian dengan menandatangani lembar informed consent. 


\section{HASIL PENELITIAN}

Tabel 1 menunjukkan responden paling banyak berada pada rentang umur 31-39 tahun dengan jumlah 45 orang $(33,6 \%)$. Mayoritas responden tidak memiliki riwayat alergi $(61,2 \%)$. Mayoritas responden telah sering menggunakan baju kerja lengan pan- kain (51,5\%). Mayoritas responden mempunyai masa kerja kategori lama atau masa kerja lebih dari sama dengan 3 tahun $(53,7 \%)$. Sebagian besar responden juga telah mencuci tangan setelah bekerja (97\%), mandi minimal 2 kali sehari (99,3\%). Akan tetapi mayoritas responden belum meng-

Tabel 1. Distribusi Karakteristik Responden

\begin{tabular}{|c|c|c|c|}
\hline \multicolumn{2}{|r|}{ Variabel } & \multirow{2}{*}{$\begin{array}{c}\text { Frekuensi } \\
21\end{array}$} & \multirow{2}{*}{$\frac{\text { Persentase }}{15.7}$} \\
\hline \multirow{5}{*}{ Umur } & $22-30$ & & \\
\hline & $31-39$ & 45 & 33.6 \\
\hline & $40-48$ & 43 & 32.1 \\
\hline & $49-57$ & 23 & 17.2 \\
\hline & $58-66$ & 2 & 1.5 \\
\hline \multirow{3}{*}{ Riwayat Alergi } & Memiliki riwayat alergi & 0 & 0 \\
\hline & Tidak memiliki riwayat alergi & 82 & 61.2 \\
\hline & Tidak mengetahui adanya alergi & 52 & 38.8 \\
\hline \multirow{3}{*}{$\begin{array}{c}\text { Penggunaan Baju Kerja } \\
\text { Lengan Panjang dan Sar- } \\
\text { ung Tangan }\end{array}$} & Tidak pernah & 0 & 0 \\
\hline & Kadang-kadang & 35 & 26.1 \\
\hline & Sering & 99 & 73.9 \\
\hline \multirow{3}{*}{ Jenis Sarung Tangan } & Sarung tangan karet biasa & 45 & 33.6 \\
\hline & Sarung tangan karet tebal (neoprene) & 20 & 14.9 \\
\hline & Sarung tangan kain & 69 & 51.5 \\
\hline \multirow{3}{*}{ Masa Kerja } & $\leq 1$ & 28 & 20.9 \\
\hline & $1-3$ & 34 & 25.4 \\
\hline & $\geq 3$ & 72 & 53.7 \\
\hline \multirow{6}{*}{ Faktor Personal Hygiene } & Mencuci tangan setelah bekerja & 130 & 97 \\
\hline & Tidak mencuci tangan setelah bekerja & 4 & 3 \\
\hline & Mengganti pakaian kerja setiap hari & 2 & 1.5 \\
\hline & Tidak mengganti pakaian kerja setiap hari & 132 & 98.5 \\
\hline & Mandi minimal 2 kali sehari & 133 & 99.3 \\
\hline & Tidak mandi minimal 2 kali sehari & 1 & 0.7 \\
\hline \multirow{2}{*}{ Dermatitis } & Mengalami dermatitis & 59 & 44 \\
\hline & Tidak mengalami dermatitis & 75 & 56 \\
\hline
\end{tabular}

Sumber: Data Primer, 2020

jang dan sarung tangan pada saat bekerja dalam kurun waktu 1 bulan terakhir $(73,9 \%)$. Sedangkan jenis sarung tangan yang paling banyak digunakan oleh para responden tersebut adalah sarung tangan ganti pakaian kerja setiap hari $(98,5 \%)$. Sebanyak $44 \%$ responden mengalami dermatitis.

Tabel 2 menunjukkan hasil uji $C h i$ square hubungan antara masa kerja dan 
penggunaan baju kerja lengan panjang dan sarung tangan dengan dermatitis. Dari hasil uji tersebut didapatkan nilai $\mathrm{p}=0.000(\mathrm{p}<$ 0.05), sehingga dapat disimpulkan terdapat hubungan yang bermakna antara masa kerja dengan dermatitis. Pada penggunaan baju kerja lengan panjang dan sarung tangan regresi logistik berganda menunjukkan bahwa semua variabel mempunyai nilai $\mathrm{p}<$ 0.05. Hal ini berarti variabel-variabel tersebut mempunyai pengaruh yang signifikan terhadap dermatitis. Berdasarkan nilai odds ratio dapat disimpulkan bahwa responden dengan masa kerja lama mempunyai risiko

Tabel 2. Hasil Uji Chi Square Hubungan Masa Kerja dengan Dermatitis

\begin{tabular}{cc}
\hline Variabel & p-value \\
\hline Masa Kerja & 0.000 \\
Penggunaan Baju Kerja Lengan Panjang dan Sarung Tangan & 0.003 \\
\hline
\end{tabular}

Sumber: Data Primer, 2020

diperoleh nilai $\mathrm{p}=0.003(\mathrm{p}<0.05)$ yang berarti terdapat hubungan yang bermakna antara penggunaan baju kerja lengan panjang dan sarung tangan dengan dermatitis. Berdasarkan hasil perhitungan risiko prevalensi dengan pendekatan odds ratio didapatkan bahwa responden dengan masa kerja kurang dari 3 tahun berisiko 0,17 kali lebih besar terkena dermatitis dibanding responden dengan masa kerja lebih dari 3 tahun. Sedangkan responden yang hanya kadang-kadang menggunakan baju kerja lengan panjang dan sarung tangan mempunyai risiko 3,357 kali lebih besar terkena dermatitis dibanding pekerja yang sering menggunakan alat tersebut.

Tabel 3 menunjukkan hasil regresi logistik berganda antara masa kerja dan penggunaan baju kerja lengan panjang dan sarung tangan dengan dermatitis. Hasil uji untuk mengalami dermatitis 6,701 kali lebih besar dibandingkan dengan responden dengan masa kerja baru. Sedangkan responden dengan masa kerja sedang mempunyai risiko 4,359 kali lebih besar untuk mengalami dermatitis dibandingkan responden dengan masa kerja baru. Nilai odds ratio pada variabel penggunaan baju kerja lengan panjang dan sarung tangan menunjukkan bahwa penggunaan baju kerja lengan panjang dan sarung tangan dengan intensitas sering dapat menurunkan risiko terkena dermatitis sebesar $0.341 \mathrm{kali}$ dibandingkan dengan intensitas pemakaian yang hanya kadang-kadang.

Tabel 4 menunjukkan hasil bahwa pada kategori masa kerja kurang dari sama dengan 1 tahun ada 11 responden yang tidak menderita dermatitis dan 17 responden menderita dermatitis. Pada kategori masa 
kerja antara 1 sampai 3 tahun terdapat 10 responden tidak menderita dermatitis dan 24 responden menderita dermatitis. Pada kategori masa kerja lebih dari sama dengan 3 tahun terdapat 54 responden tidak menderita dermatitis dan 18 responden menderita dermatitis. disimpulkan bahwa kedua variabel bebas tersebut secara signifikan memengaruhi adanya dermatitis. Nilai odds ratio menunjukkan bahwa masa kerja lama menyebabkan peningkatan risiko dermatitis sebesar 6,701 kali lebih besar dibandingkan responden yang mempunyai masa kerja baru.

Tabel 3. Hasil Uji Regresi Logistik Berganda

\begin{tabular}{lcc}
\hline \multicolumn{1}{c}{ Variabel } & p-value & OR \\
\hline Masa Kerja & & \\
-Masa Kerja Baru & 0.000 & 1 \\
-Masa Kerja Sedang & 0.002 & 4,359 \\
-Masa Kerja Lama & 0.000 & 6,701 \\
Penggunaan Baju Kerja Lengan Panjang dan Sarung Tangan & & \\
-Kadang & 0.000 & 1 \\
-Sering & 0.017 & 0.341 \\
\hline
\end{tabular}

Sumber: Data Primer, 2020

Tabel 5 menunjukkan hasil hasil bahwa pada kategori penggunaan baju kerja lengan panjang dan sarung tangan yang jarang terdapat 12 responden tidak menderita dermatitis dan 23 responden menderita dermatitis. Sedangkan pada kategori penggunaan baju kerja lengan panjang dan sarung tangan dengan kategori sering terdapat 63 responden tidak menderita dermatitis dan 36 responden menderita dermatitis.

\section{PEMBAHASAN}

Berdasarkan hasil uji multivariabel menggunakan regresi logistik berganda didapatkan hasil bahwa kedua variabel mempunyai nilai $\mathrm{p}<0.05$ sehingga dapat
Sedangkan responden dengan masa kerja sedang mempunyai risiko 4,359 kali lebih besar untuk mengalami dermatitis dibandingkan responden dengan masa kerja baru Pada variabel penggunaan baju kerja lengan panjang dan sarung tangan menunjukkan bahwa penggunaan baju kerja lengan panjang dan sarung tangan dengan intensitas sering dapat menurunkan risiko terkena dermatitis sebesar 0.341 kali dibandingkan dengan intensitas pemakaian yang hanya kadang-kadang.

Masa kerja adalah rentang waktu pekerja selama menjadi pekerja dalam suatu perusahaan atau instansi sehingga membentuk pengalaman, pengetahuan dan ket- 
erampilan kerja (Septiana, 2015). Masa kerja memengaruhi frekuensi paparan yang dialami oleh pekerja. Semakin lama masa kerja, semakin lama frekuensi paparan maka semakin banyak bahan yang mampu masuk dan mengiritasi kulit pekerja. Kulit yang semakin sering terkena paparan akan kerja kurang dari 3 tahun. Diketahui juga masa kerja merupakan faktor risiko terjadinya dermatitis kontak iritan.

Masa kerja berhubungan dengan lamanya kontak pekerja dengan lingkungan kerjanya. Semakin lama masa kerja, maka akumulasi lama kontak pekerja tersebut

Tabel 4. Hasil Crosstab Masa Kerja dengan Dermatitis

\begin{tabular}{|c|c|c|c|c|}
\hline \multicolumn{2}{|c|}{ Crosstab } & \multicolumn{2}{|c|}{ Diagnosis Dokter } & \multirow{2}{*}{ Tota } \\
\hline & & Tidak Menderita & Menderita & \\
\hline \multirow{3}{*}{ Masa Kerja } & $\leq 1$ tahun & 11 & 17 & 28 \\
\hline & 1-3 tahun & 10 & 24 & 34 \\
\hline & $\geq 3$ tahun & 54 & 18 & 72 \\
\hline \multicolumn{2}{|c|}{ Total } & 75 & 59 & 134 \\
\hline
\end{tabular}

Sumber: Data Primer, 2020

timbul kerusakan, karena pekerjaan dilakukan setiap hari, maka kerusakan pada kulit akan terus menerus timbul bahkan saat kerusakan sebelumnya belum sepenuhnya pulih, hal ini dapat menyebabkan kelainan kulit (Audina et al., 2017). Penelitian ini sesuai dengan penelitian Garmini (2018) tentang kelainan kulit pada pekerja pabrik tahu, secara statistik masa kerja mempunyai hubungan yang signifikan dengan kejadian dermatitis kontak iri$\tan (p=0.019)$ dengan nilai OR 3,750, sehingga dapat disimpulkan bahwa pekerja yang mempunyai masa kerja lebih dari 3 tahun mempunyai risiko untuk terkena dermatitis kontak iritan 3,750 kali lebih besar dibanding pekerja yang mempunyai masa juga akan semakin besar. Dalam penelitian ini, semakin lama masa kerja, maka lama kontak pekerja dengan sampah yang mengandung sampah B3 maupun jamur dan bakteri juga akan semakin lama. Penelitian Pradaningrum et al., (2018) menyebutkan bahwa lama kontak dengan bahan kimia akan berbanding lurus dengan keluhan dermatitis kontak pada pekerja. Kontak dengan bahan iritan dapat merusak lapisan pada kulit, denaturasi protein, menyingkirkan lemak di lapisan kulit dan mengubah daya ikat air pada kulit. Bahan iritan dapat merusak membran lemak keratinosit dan juga menembus membran sel sehingga dapat menimbulkan peradangan pada kulit. Peradangan tersebut 
akan menimbulkan kelainan kulit disertai dengan gejala dermatitis (Wijaya et al., 2016). Sehingga semakin lama kontak, akan semakin merusak sel kulit hingga lapisan lebih dalam dan risiko terjadinya dermatitis akan semakin tinggi (Zania et al., 2018). hilang dan bersih. Baju yang digunakan bekerja lebih dari satu kali tanpa dicuci terlebih dahulu berpotensi menyebabkan tubuh terpajan bakteri yang terbawa dari lingkungan kerja (Ferusgel \& Nasution, 2018). Kebiasaan tersebut yang selalu berulang-

Tabel 5. Hasil Crosstab Baju Kerja Lengan Panjang dan Sarung Tangan dengan Dermatitis

\begin{tabular}{|c|c|c|c|c|}
\hline \multirow{2}{*}{\multicolumn{2}{|c|}{ Crosstab }} & \multicolumn{2}{|c|}{ Diagnosis Dermatitis } & \multirow{2}{*}{ Total } \\
\hline & & Tidak Menderita & Menderita & \\
\hline Penggunaan Baju Kerja & Kadang & 12 & 23 & 35 \\
\hline \multicolumn{5}{|l|}{ Lengan Panjang dan Sarung } \\
\hline Tangan & Sering Menggunakan & 63 & 36 & 99 \\
\hline \multicolumn{2}{|c|}{ Total } & 75 & 59 & 134 \\
\hline
\end{tabular}

Sumber: Data Primer, 2020

Kebersihan perorangan atau personal hygiene adalah konsep dasar dari pembersihan, kerapihan dan perawatan badan kita. Sangat penting untuk pekerja memelihara kesehatan dan keselamatannya di tempat kerja. Kebersihan perorangan dapat menekan dan mencegah penyebaran bakteri maupun jamur yang yang dapat menimbulkan dermatitis (Putri et al., 2017). Kebiasaan mayoritas responden yang tidak mengganti pakaian kerja mereka setiap hari juga menjadi faktor timbulnya dermatitis. Dalam penelitian ini, faktor personal hygiene yang dimaksud adalah kebiasaan mandi, cuci tangan setelah bekerja, dan mengganti pakaian kerja. Seperti halnya baju kerja yang digunakan untuk bekerja harus dicuci atau diganti setiap hari agar kuman dan bakteri yang menempel dibaju ulang, dengan masa kerja lama menyebabkan risiko terjadinya dermatitis semakin besar. Frekuensi paparan dan masa kerja yang lama, dapat lebih sering membuat semakin banyak bahan yang mampu masuk ke kulit dan menimbulkan reaksi. Selain itu, kulit yang semakin sering terkena, menimbulkan kerusakan pada lapisan kulit yang terpapar secara terus-menerus, hal ini mengakibatkan munculnya kelainan pada kulit (Audina et al., 2017).

Pada hasil uji variabel penggunaan baju kerja lengan panjang dan sarung tangan menunjukkan bahwa penggunaan yang sering dapat menurunkan risiko dermatitis sebesar 0.341 kali dibandingkan jika jarang menggunakan. Hal ini sesuai dengan pernyataan Tarwaka (2017) bahwa APD berfungsi untuk memberikan perlindungan bagi 
pekerja dari bahaya yang ada di lingkungan kerjanya. Alat pelindung diri dapat mengurangi paparan langsung dari lingkungan kerja yang dapat menimbulkan lesi pada daerah yang kontak dengan lingkungan dan alat kerja. Kontak langsung kulit dengan bahan berbahaya yang ada pada sampah dapat menimbulkan abrasi yang menyebabkan kulit menjadi terkikis dan bahan iritan semakin mudah untuk menimbulkan iritasi pada kulit (Dewi et al., 2019). Lesi yang terjadi merusak barrier pada kulit pekerja sehingga bahan iritan dan alergen dapat mudah masuk dan merusak kulit (Amado et al., 2012). Hasil penelitian ini juga sejalan dengan penelitian yang dilakukan oleh Dahliana (2017) tentang hubungan tingkat kepatuhan penggunaan APD dengan terjadinya penyakit dermatitis pada pekerja bagian spraying bahwa ada hubungan yang signifikan antara masa kerja dengan kejadian dermatitis dengan nilai $\mathrm{p}=0.01$. Nilai $\mathrm{RP}=6,406$ menunjukkan bahwa pekerja yang tidak patuh memakai APD berisiko 6,406 kali lebih besar mengalami dermatitis dibandingkan dengan pekerja yang patuh menggunakan APD.

Proses kerja petugas pengangkut sampah yang kontak berkali-kali dengan sampah membuat waktu lama paparan juga meningkat. Baju kerja lengan panjang dan sarung tangan yang sesuai dibutuhkan untuk mengurangi risiko terkena dermatitis yang diakibatkan oleh kontak kulit dengan sampah-sampah tersebut. Seperti yang disebutkan Mu'min et al., (2020) bahwa sampah Bahan Berbahaya dan Beracun (B3) rumah tangga didominasi oleh sampah produk perawatan diri di mana sampah tersebut kadang masih terdapat sisa cairan yang jika terkena kulit akan bersifat mengiritasi. Bahan sarung tangan yang terbuat dari kain tidak dapat menghalangi cairan tersebut untuk tidak kontak dengan kulit karena sifat bahan yang menyerap cairan. Penggunaan baju kerja lengan panjang dan sarung tangan dapat berfungsi sebagai barrier antara kulit dan bahan kimia yang berbahaya dari sampah sehingga meminimalkan risiko terkena dermatitis. Meskipun telah terdapat barrier, upaya pengendalian risiko lain yang efektif juga diperlukan.

Mayoritas responden menggunakan baju kerja lengan panjang dan sarung tangan, namun bahan dan desain sarung tangan yang digunakan kurang tepat. Menurut Naiheli (2019), sarung tangan yang tepat adalah sarung tangan yang terbuat dari karet atau plastik dengan rancangan menutupi bagian telapak tangan hingga lengan. Sedangkan menurut Occupational Safety and Health Administration (OSHA) sarung tangan yang tepat berdasarkan bahan yang kontak dengan pekerja pengangkut sampah adalah sarung tangan neoprene, yaitu sarung tangan karet yang berbahan tebal dan 
tidak mudah sobek. Sarung tangan lateks kurang disarankan karena mudah sobek dan kadang menimbulkan alergi. Selain dari bahan sarung tangan yang digunakan, penggunaannya pun hanya sebatas pergelangan tangan sehingga lengan yang hanya tertutupi kaos tidak terlindungi secara maksimal dari bahaya bahan kimia akibat lingkungan kerja. Belum adanya standar khusus dari pemerintah mengenai alat pelindung diri yang harus dipakai petugas pengangkut sampah juga menyebabkan kurangnya perhatian pemerintah daerah mengenai hal tersebut.

\section{KESIMPULAN}

Pekerja dengan masa kerja lama mempunyai risiko terkena dermatitis sebesar 6,701 kali lebih besar dibanding pekerja dengan masa kerja baru. Sedangkan penggunaan baju kerja lengan panjang dan sarung tagan dengan intensitas sering dapat menurunkan risiko dermatitis sebesar 0.341 kali dibandingkan tidak menggunakan alatalat tersebut. Penelitian ini menemukan bahwa ada hubungan antara masa kerja dan penggunaan baju kerja lengan panjang dan sarung tangan dengan dermatitis pekerja pengangkut sampah di Surakarta, di mana proporsi kejadian dermatitis pada penelitian ini adalah $44,02 \%$.

\section{SARAN}

Berdasarkan hasil penelitian, beberapa saran yang dapat diajukan, antara lain pembuatan standard operational procedure (SOP) oleh pemerintah Kota Surakarta, penyediaan Alat Pelindung Diri (APD) sesuai dengan standar, dan peningkatan pengetahuan pekerja pengangkut sampah mengenai penggunaan APD pada saat bekerja oleh pihak kelurahan selaku pemberi kerja. Akan tetapi perlu dilakukan penelitian lebih lanjut mengenai pengaruh bahan dan desain baju kerja lengan panjang dan sarung tangan dengan kejadian dermatitis pada pekerja pengangkut sampah sehingga dapat ditentukan bahan dan desain yang sesuai untuk pekerja tersebut.

\section{UCAPAN TERIMA KASIH}

Ucapan terima kasih diberikan kepada Pemerintah Kecamatan Jebres yang telah memberikan izin kepada penulis untuk melangsungkan penelitian dari bulan JanuariAgustus 2020.

\section{DAFTAR PUSTAKA}

Amado, A., Sood, A., \& Taylor, J.S. (2012). Fitzpatrick's Dermatology in General Medicine. New York: McGrawHill.

Audina, D., Asih, B., \& Aryoko, W. (2017). Faktor Penyebab Terjadinya Dermatitis Kontak Akibat Kerja pada Pekerja Salon. Jurnal Kedokteran Diponegoro, 6, 1-11. https:// ejournal3.undip.ac.id/index.php/ medico/article/view/18801/17884 
Badan Pusat Statistik Kota Surakarta. (2019). Kecamatan Jebres dalam angka tahun 2019. https:// surakartakota.bps.go.id/ publication/2019/09/26/ d9191571ec8f8a41a03640b1/ kecamatan-jebres-dalam-angka2019.html

Cruvinel, V. R. N., Marques, C. P., Cardoso, V., Novaes, M. R. C. G., Araújo, W. N., Angulo-Tuesta, Escalda, P. M. F., Galoto, D., Brito, P., \& da Silva, E. N. (2019). Health conditions and occupational risks in a novel group: waste pickers in the largest open garbage dump in Latin America. BMC public health, 19(1), 1-15. $\quad$ https://doi.org/10.1186/ s12889-019-6879-x

Dahliana. (2017). Hubungan Tingkat Kepatuhan Pekerja dalam Pemakaian APD dengan Terjadinya Penyakit Dermatitis pada Pekerja Spraying di PT. Rapp Estate Teso Pekanbaru Riau Tahun 2017 [Fakultas Kesehatan Masyarakat Universitas Sumatera Utara]. http:// repositori.usu.ac.id/ handle/123456789/21820

Dewi, I. A., Wardhana, M., \& Puspawati, N. M. (2019). Prevalensi dan Karakteristik Dermatitis Kontak Akibat Kerja pada Nelayan di Desa Perancak Jembrana Tahun 2018. Jurnal Medika Udayana, 8(12), 1-6. https://ojs.unud.ac.id/index.php/ eum/article/view/55897

Elviarni, \& Dode, H. (2018). Faktor-Faktor yang Berhubungan dengan Penggunaan Alat Pelindung Diri (APD) pada Petugas Kebersihan TPA Puuwatu Kota Kendari. Jurnal MJPH, $\quad 1(2), \quad 1-13 . \quad$ https:// mjph.stikes-mw.ac.id/index.php/ mjph/article/view/77/43
Ferusgel, A., \& Nasution, R. M.-B. (2018). Keluhan Gangguan Kulit pada Pemulung Wanita di Tempat Pembuangan Akhir Terjun. Jurnal Aisyah : Jurnal lmu Kesehatan, 3 (2), 145-152. https:// doi.org/10.30604/jika.v3i2.127

Garmini, R. (2018). Faktor yang Mempengaruhi Kejadian Dermatitis Kontak Iritan pada Pekerja Pabrik Tahu. Babul Ilmi-Jurnal Ilmiah Multi Science Kesehatan, 9(2), 207217. https://jurnal.stikes-aisyiyahpalembang.ac.id/index.php/Kep/ article/view/133

Lesmana, R. Y. (2016). Layanan Persampahan di Kota Surakarta dengan Pemetaan Berbasis Sistem Informasi Geografis. Media Ilmiah Teknik Lingkungan, 1(1), 11-21. https:// journal.umpalangkaraya.ac.id/ index.php/mitl/article/view/135

Lokahita, B., Samudro, G., Huboyo, H. S., Aziz, M., \& Takahashi, F. (2019). Energy recovery potential from excavating municipal solid waste dumpsite in Indonesia. Energy Procedia, 158, 243-248. https:// doi.org/10.1016/ j.egypro.2019.01.083

Mu'min, Mizwar, A., \& Mahyudin, R. P. (2020). Studi Pengelolaan Sampah B3 Rumah Tangga di Kabupaten Banjar Wilayah Barat (Kecamatan Suangai Tabuk, Kertak Hanyar dan Gambut). Jurnal Teknik Lingkungan Universitas Lambung Mangkurat, 3(1), 61-68. http://jtam.ulm.ac.id/index.php/jerni h/article/view/483

Nam, P. T., Dung, N. H., Oanh, N. K., \& Thu, H. T. (2020). Factors affecting the access to health services among waste collectors in Hanoi, Vietnam: A qualitative study. AIMS Public 
Health, 7(3),

478.

https://doi.org/10.3934/publichealth. 2020039

Naiheli, Y. M. (2019). Studi Penggunaan Alat Pelindung Dri Pada Petugas Pengangkut Sampah di Dinas Kebersihan Kota Kupang [Politeknik Kesehatan Kupang]. http://repository.poltekeskupang.ac.i $\mathrm{d} / \mathrm{id} /$ eprint/1193

Pradaningrum, S., Lestantyo, D., \& Jayanti, S. (2018). Hubungan Personal hygiene, Lama Kontak, dan Masa Kerja dengan Gejala Dermatitis Kontak Iritan Pada Pengrajin Tahu Mrican Semarang. Jurnal Kesehatan Masyarakat, 6(4), 378-386. https://ejournal3.undip.ac.id/index.p $\mathrm{hp} / \mathrm{jkm} /$ article/view/21442

Putri, S. A., Nirmala, F., \& Akifah. (2017). Faktor-Faktor yang Berhubungan dengan Gejala Dermatitis Kontak pada Pekerja Bengkel Motor di Wilayah Kota Kendari Tahun 2016. Jurnal Imliah Kesehatan Masyarakat, 2(6), 1-8. http://dx.doi.org/10.37887/jimkesma s.v2i6.2856

Sarfiah, Asfian, P., \& Ardiansyah, R. T. (2016). Faktor-Faktor yang Berhubungan dengan Dermatitis Kontak Iritan pada Nelayan di Desa Lamanggau Kecamatan Tomia Kabupaten Wakatobi. Jurnal Ilmiah Mahasiswa Kesehatan Masyarakat. 1(3).

http://dx.doi.org/10.37887/jimkesma s.v1i3.1232

Sudibyoa, H., Majid A. I., Pradanaa, Y. S., Budhijantoa, W., Deendarlianto, Budiman A., (2017). Technological evaluation of municipal solid waste management system in Indonesia. Energy Procedia, 105, 263-269. https://doi.org/10.1016/j.egypro.201
7.03 .312

Septiana, V. A. (2015). Pengaruh Faktor Masa Kerja, Kompensasi dan Pendidikan Terhadap Motivasi Kerja Pegawai Dinas Bina Marga Provinsi Jawa Tengah dengan Produktivitas Kerja Sebagai Variabel Interventing. Journal of Management. 1(1). https://jurnal.unpand.ac.id/index.php /MS/article/view/237

Wijaya, I. P., Darmada, I. G., Rusyanti, \& Mas, L. M. (2016). Edukasi dan Penatalaksanaan Dermatitis Kontak Iritan Kronis di RSUP Sanglah Denapasar Bali Tahun 2014/2016. E-Jurnal Medika, 5(8), 1-3. https://ojs.unud.ac.id/index.php/eum /article/view/22867

Wijayanti, D. F. (2015). Hubungan Pengetahuan, Sikap dan Tindakan Penggunaan Alat Pelindung Diri Terhadap Keluhan Ganguan Kulit pada Petugas Sampah TPA Batu Layang Pontianak. Jurnal Mahasiswa PSPD FK Universitas Tanjungpura.

3(1). https://jurnal.untan.ac.id/index.php/j $\mathrm{fk} /$ article/view/16436

Zania, E., Junaid, \& Ainurafiq. (2018). Faktor-Faktor yang Berhubungan dengan Kejadian Dermatitis Kontak Pada Nelayan di Kelurahan Induha Kecamatan Latambaga Kabupaten Kolaka Tahun 2017. Jurnal Ilmiah Mahasiswa Kesehatan Masyarakat, 1(3), 1-8. http://ojs.uho.ac.id/index.php/JIMK ESMAS/article/view/5256

Zulfinar, \& Sembiring, E. (2015). Dinamika Jumlah Sampah yang Dihasilkan di Kota Bandung. Jurnal Teknik Lingkungan, 21(1), 18-28. http://dx.doi.org/10.5614\%2Fjt1.201 5.21.1.3 